THE DECLINE AND RISE OF DEMOCRACY 
THE PRINCETON ECONOMIC HISTORY OF THE WESTERN WORLD

\author{
Joel Mokyr, Series Editor
}

A list of titles in this series appears in the back of the book. 


\section{The Decline and Rise of Democracy}

A GLOBAL HISTORY FROM ANTIQUITY TO TODAY

DAVID STASAVAGE 
Copyright (C) 2020 by Princeton University Press

Requests for permission to reproduce material from this work should be sent to permissions@press.princeton.edu

Published by Princeton University Press

41 William Street, Princeton, New Jersey o8540

6 Oxford Street, Woodstock, Oxfordshire OX 201 TR

press.princeton.edu

All Rights Reserved

ISBN 978-0-691-17746-5

ISBN (e-book) 978-o-691-20195-5

Library of Congress Control Number 2020932776

British Library Cataloging-in-Publication Data is available

Editorial: Bridget Flannery-McCoy \& Alena Chekanov

Production Editorial: Ali Parrington

Jacket/Cover Design: Leslie Flis

Production: Erin Suydam

Publicity: James Schneider \& Kate Farquhar-Thomson

Jacket images: Shutterstock

This book has been composed in Arno

Printed on acid-free paper. $\infty$

Printed in the United States of America

$\begin{array}{llllllllll}10 & 9 & 8 & 7 & 6 & 5 & 4 & 3 & 2 & 1\end{array}$ 
For my parents

Barbara and Gerry 
